\title{
THE NeW SCHOOL LECTURE "AN ARMY OF WOMEN": Communist-Linked Solidarity Movements, Maternalism, and Political Consciousness in 1930s and 1940s Argentina
}

C6 T carried a package for Osvaldo Pugliese," Teresa de Gílenberg proudly recalled during our interview in 1997. One day in the late 1940s, this Communist militant of Polish origins asked Juan, a vendor in her barrio, if he would contribute potatoes and gather foods from other tradesmen in solidarity with Pugliese, a renowned tango composer, orchestra director, and Communist who was incarcerated in the infamous Villa Devoto jail. Juan brought her a large parcel containing his donations and those offered by his fellow vendors, and she personally handed it to the musician.

Gílenberg formed part of what she called an "army of women," organized through the Communist-linked Liga Argentina por los Derechos del Hombre. This army solicited, assembled, and delivered foodstuffs and other goods to imprisoned militants, and it also created networks with the jailed, their families, and neighborhood sympathizers. ${ }^{1}$ In using the phrase "army of women," Gílenberg most likely referred to the large number of women who were involved. She also seemed to evoke the quasi-military sense of dedication, unity, combativeness, bravery, and camaraderie that characterized her group. ${ }^{2}$

This is a revised version of the lecture I gave at the New School for Social Research, and sections of it preview a forthcoming chapter, "A Labor Filled With Love": Communists, Women, and Solidarity in Argentina, 1930-1946," in The Wider Arc of Revolution, Steve Sabol et al., eds., Vol. 6: Russia's Great War and Revolution, 1914-1922: The Centenary Reappraisal, (Bloomington, IN: Slavica Press, in progress). I am very grateful to Federico Finchelstein for inviting me to give the Janey lecture, and to Ben Vinson III and Eric Zolov for their guidance in the preparation of this essay. I thank Finchelstein, Zolov, Adam Jakes, Luis Herrán Avila, and other members of the audience at the New School, as well as Eleonora Ardanaz, Katherine Marino, Jessica Stites Mor, Margaret Power, Adriana Valobra, and Barbara Weinstein for their valuable suggestions. I also thank Argentine and Uruguayan colleagues and archivists, too numerous to mention, for their generous guidance and support. Unless otherwise stated, all periodicals cited are from Buenos Aires.

1. Teresa Gílenberg, interview with author, Buenos Aires, 1997.

2. Gílenberg was not expressing sympathy with the Argentine armed forces, unlike the militarized women volunteers of CEMA-Chile who supported Augusto Pinochet's regime (1973-89). See María Elena Valenzuela, $L a$ mujer en el Chile militar: todas íbamos a ser reinas (Santiago: Chile y América, CESOC, 1987); and Jadwiga E. Pieper Mooney, The Politics of Motherhood: Maternity and Women's Rights in Twentieth-Century Chile (Pittsburgh: University of Pittsburgh Press, 2009), 141. 
Her term is striking in that it alludes - probably unintentionally - to a path for women to acquiring citizenship. Male citizenship in Argentina and elsewhere rested partly on serving in the military. In an effort to extend such rights to women, Santiago Fassi introduced a bill in Congress in 1938 that would have permitted women to vote if they offered "auxiliary service compatible with their sex" to the armed forces. Congress did not pass the bill, but the suggestion and its connotations lingered. ${ }^{3}$ Gílenberg and the Liga asserted women's citizenship by fostering a well-organized and courageous rearguard activity in solidarity with Communist Party activists.

The Liga Argentina por los Derechos del Hombre is one of the Communistinfluenced solidarity movements of the 1930s and 1940s that I will analyze. Founded in 1937, the roots of this group reached back to 1922 and its efforts then to help political prisoners. Communists helped establish the Agrupación Femenina Antiguerrera in 1935 and the feminist Unión Argentina de Mujeres in 1936. Also tied to the party were Spanish Republican aid efforts such as the Comité Argentino de Mujeres Pro Huérfanos Españoles and the pro-Allied Junta de la Victoria, of the Spanish Civil War and World War II eras, respectively. Women in or close to the Communist Party were instrumental in creating these solidarity organizations and setting their agendas.

Latin Americanists frequently refer to solidarity without explaining clearly what it means, perhaps assuming that we know solidarity when we see it. ${ }^{4}$ Thus, one must venture outside the discipline to find fuller treatments. Even so, solidarity remains a vague and often slippery concept. For this reason, rather than rely on a single definition, I draw on ideas from several scholars. The activists under study participated in what philosopher Sally Scholtz calls "political solidarity," a type of social movement characterized by a "moral relation" that takes concrete actions to construct a better world, fight injustice, and help its victims. ${ }^{5}$ Catherine Sameh, a specialist in gender and sexuality studies, has developed the notion of this "moral relation," explaining that "as a practice, solidarity attempts to build ethical relationships based on equity while acknowledging and challenging the economic and political structures that create inequality between people." Sameh writes, "As a set of feelings and aspirations, solidarity

3. Gregory Hammond, The Women's Suffrage Movement and Feminism in Argentina from Roca to Perón (Albuquerque: University of New Mexico Press, 2011), 137. See also Adriana María Valobra, Del hogar a las urnas: recorridos de la ciudadanía politica femenina. Argentina, 1946-1955 (Rosario: Prohistoria, 2010), 31 and elsewhere; and Jocelyn Olcott, Revolutionary Women in Postrevolutionary Mexico (Durham: Duke University Press, 2005), 11, 20-21.

4. An important exception is Christine Hatsky and Jessica Stites Mor, "Latin American Transnational Solidarities: Contexts and Critical Research Paradigms," Journal of Iberian and Latin American Research 20:2 (2014): 127-140.

5. Sally J. Scholtz, Political Solidarity (University Park: Pennsylvania State University Press, 2008), 6. 
might be imagined as a bridge that enables people to connect to or meet each other across significant divides," and goes on to state that "the concept of solidarity emphasizes trust, justice, equity, democracy, mutuality, and love in the building of movements, ties, and relationships that seek to overturn, rather than reproduce, relations of inequality." Solidarity, according to philosopher Kurt Bayertz, also "denotes the emotional cohesion between the members of these social movements and the mutual support they give each other in their battle for common goals" and, one might add, their resistance to persecution. ${ }^{7}$ Moreover, as historians Margaret Power and Julie Charlip have pointed out, engaging in solidarity empowers activists by building courage and self-worth. ${ }^{8}$ These characteristics overlap and intersect with the image of an army of women.

Surprisingly, there are relatively few historical studies of solidarity in Latin America, Communist-linked or not. Most works focused on US movements supporting Latin American causes until recent years, which have witnessed writings on South-North and South-South networks, such as the ones I examine. ${ }^{9}$ Even so, only a handful of writings touch on women. ${ }^{10}$ Similarly, the literature on Communist women in Argentina and Latin America as a whole before 1945 is thin in some respects. ${ }^{11}$ Although new work is emerging,

6. Catherine Sameh, "Solidarity," in Gender: Love. MacMillan Interdisciplinary Handbooks, Jennifer C. Nash. ed. (Farmington Hills, MI: MacMillan Reference USA, 2016), 181-182.

7. Kurt Bayertz, "Four Uses of 'Solidarity,'” in Solidarity, Kurt Bayertz, ed. (Dordrecht: Kluwer, 1999), 16, quoted in Scholtz, Political Solidarity, 10.

8. Margaret Power and Julie A. Charlip, "Introduction: On Solidarity," Latin American Perspectives 36:6 (November 2009): 3-4.

9. Saúl Luis Casas, "La guerra civil española y la sociedad política argentina en el marco de la ayuda a la República (1936-1941)" (MA thesis, Universidad Nacional de la Plata, 2005); and "La guerra civil española y su recepción en la Argentina: las mujeres en los comités de ayuda al sector republicano," Cuadernos de H Ideas 7:7 (December 2013), http://perio.unlp.edu.ar/ojs/index.php/cps/article/view/2065, accessed January 13, 2017; Eleonora Ardanaz, "Maternalismo y política en el antifascismo argentino: el caso del Comité Argentino Pro Huérfanos Españoles," paper delivered at the Latin American Studies Association meeting, New York, May 2016; Margaret Power, "The Puerto Rican Nationalist Party, 1927 to 1954: Anti-Colonialism, Transnational Solidarity, and Gender Transgression," book project, in progress; Jessica Stites Mor, ed., Human Rights and Transnational Solidarity in Cold War Latin America (Madison: University of Wisconsin Press, 2013); Vania Markarian, Left in Transformation: Uruguayan Exiles and the Latin American Human Rights Networks, 1967-1984 (New York: Routledge, 2005); Raanan Rein, "A Trans-National Struggle with National and Ethnic Goals: Jewish Argentines and Solidarity with the Republicans during the Spanish Civil War," 171-182, and other articles in Journal of Iberian and Latin American Research 20:2 (2014); Sandra McGee Deutsch, "Argentine Women Against Fascism: The Junta de la Victoria, 1941-1947," Politics, Religion, and Ideology 13:2 (2012): 221-236; and "Engendering Antifascism: The Junta de la Victoria of Argentina in Transnational Perspective, 1930-1947," book project, in progress; Carlos Zubillaga, Niños de la guerra. Solidaridad uruguaya con la República Española, 1936-1939 (Montevideo: Linardi y Risso, 2013); Christine Hatsky, Cubans in Angola: SouthSouth Cooperation and Transfer of Knowledge, 1976-1991, Mair Edmunds-Harrington, trans. (Madison: University of Wisconsin Press, 2015).

10. Namely, Ardanaz, "Maternalismo"; Casas, "Las mujeres"; Deutsch, "Argentine Women" and "Engendering”; and Zubillaga, Niños.

11. On Argentina, see Deutsch, "Argentine Women"and "Engendering"; Adriana Valobra, "Partidos, tradiciones y estrategias de movilización social: de la Junta de la Victoria a la Unión de Mujeres de la Argentina,” Revista Prohistoria 9:9 (2005): 67-82, and "Formación de cuadros y frentes populares: relaciones de clase y género en el Partido Comunista de Argentina, 1935-1951," Revista Izquierdas 23 (April 2015): 127-156; Clara del Franco, Mujeres, ese fuego, esas luchas: 1930-1960 (Buenos Aires: Cuadernos Marxistas, 2011); Eleonora Ardanaz, "Con el puño 
existing studies do not dissect solidarity or describe the human rights and peace movements that accounted for a significant portion of Communist women's activism in this period. Centering on solidarity provides clues about Argentine and Latin American women's mobilization, strategies, and gendered practices. It also highlights the significance of the Communist Party, the leading revolutionary force in Argentina in the 1930s and 1940s. ${ }^{12}$ The history of solidarity reveals Argentine communists' enduring interest in organizing women and supporting women's rights. Finally, the solidarity movements I examine opposed fascism. Their activism demonstrates the importance of antifascism for the Communist Party and the left in Argentina, and possibly the entire region.

Women solidarity activists in these years saw themselves as engaged in a lifeand-death struggle pitting the forces of democracy and civilization against fascists, who epitomized dictatorship and barbarism. ${ }^{13}$ One might argue that such ideas resonated with women because they supported deeply rooted beliefs about women's place. Indeed, specialists usually have attributed Latin American women's political engagement to maternalism, the notion of "gender difference based on motherhood as the foundation for reform and activism."14 This notion also rests upon an exaltation of women's roles in the home and the home writ large. As mothers, women were charged with tending to their families,

en alto: Sara Fradkin y la lucha antifascista judía," in Mujeres en espacios bonaerenses, Adriana Valobra, ed. (La Plata: EDULP, 2009), 111-124; Liliana Cristina Tuccio, "La mujer obrera argentina y su participación en las organizaciones sindicales entre 1930 y 1943" (Licenciatura thesis, Universidad de Buenos Aires, 2002); Torcuato Di Tella, "La Unión Obrera Textil 1930-1945," in Sindicalistas como las de antes, Torcuato Di Tella, ed. (Buenos Aires: Biblos, 1993), 169-214; Verónica Norando, "Relaciones de género y militancia política: las obreras textiles y el comunismo entre 1936 y 1946," Trabajos y Comunicaciones 39 (2013): http://www.memoria.fahce.unlp.edu.ar/art_revistas/pr.6085/ pr.6085.pdf, accessed August 19, 2015. On the rest of Latin America, see Gerardo Leibner, Camaradas y compañeros. Una historia politica y social de los comunistas del Uruguay (Montevideo: Trilce, 2011); Karin Rosemblatt, Gendered Compromises: Political Cultures and the State in Chile, 1920-1950 (Chapel Hill: University of North Carolina Press, 2000); Corinne Antezana-Pernet, "Mobilizing Women in the Popular Front Era: Feminism, Class, and Politics in the Movimiento Pro Emancipación de la Mujer Chilena (MEMCh), 1935-1950" (PhD diss.: University of CaliforniaIrvine, 1996); Olcott, Revolutionary Women; Esperanza Tuñón Pablos, Mujeres que se organizan: el Frente Único Pro Derechos de la Mujer, 1935-1938 (Mexico City: Universidad Nacional Autónoma de México, 1992); and Eugenia Rodríguez Sáenz, "Madres, reformas sociales y sufragismo: el Partido Comunista de Costa Rica y sus discursos de movilización política de las mujeres (1931-1948)," Cuadernos Intercambio 11:1 (2014): 49-84. An important compendium of articles on Communist women in Latin America is about to appear: Adriana Valobra and Mercedes Yusta Rodrigo, eds., Queridas camaradas. Historias iberoamericanas de mujeres comunistas, 1935-1975 (Buenos Aires: Miño y Dávila, forthcoming).

12. On the importance of the Communist party, see Jorge Cernadas, Roberto Pittaluga, and Horacio Tarcus, "La historiografía sobre el Partido Comunista de la Argentina: un estado de la cuestión," El Rodaballo 4:8 (Fall/Winter 1998): 31-40; Hernán Camarero, A la conquista de la clase obrera: los comunistas y el mundo de trabajo en la Argentina, 1920-1935 (Buenos Aires: Siglo XXI, 2007). Anarchists and other women also had solidarity groups. On anarchists, see Gisela Manzoni, “Antimilitarismo y antifascismo: particularidades de la intervención pública de las anarquistas argentinas," Cuadernos del Sur (Bahía Blanca) 41 (2012): 189-213.

13. There were many interpretations of democracy in the 1930s and 1940s, and Communists defined democracy differently than liberals. See Deutsch, "Argentine Women," 233.

14. Melissa R. Klapper, "Those by Whose Side We Have Labored: American Jewish Women and the Peace Movement between the Wars," Journal of American History 97:3 (December 2010): 640. 
helping their husbands, nourishing bonds in the community, and spreading ethical values. Whether they had given birth or not, all women were mothers or potential mothers, and as such they presumably shared an identity and a compassionate and caring nature.

Some feminists insisted that these traits, which they regarded as inherent, made women uniquely suited for social welfare and peacemaking tasks. Furthermore, in their view, women's vital reproductive duties entitled them to equal rights. They also couched their demands for full citizenship in arguments that it would help women serve their families and society. Maternalism was a heartfelt sentiment for many, but it was also the most durable and versatile sword in women's arsenal, honed by decades of use. As such, it served as a tool for unifying diverse women and justifying their entry into the polity. ${ }^{15}$ It is tempting to say that fascism and related threats to morality, peace, and women's rights in the 1930s and 1940s seemed to attack women's mission of encouraging amity and harmony in the family and society and therefore pushed them into the political sphere.

I have used maternalism to explain women's political involvement, but as my work on solidarity has evolved I have come to question this assumption. ${ }^{16}$ The concept of maternalism tends to homogenize women and erase their political experience and multiple identities. The militants in Gílenberg's army of women were not exclusively caregivers. A careful examination of the solidarity movements' statements and activities, as well as of members' lives and words,

15. Among many works on Argentina and the Southern Cone, see Asunción Lavrin, Women, Feminism, and Social Change in Argentina, Chile, and Uruguay, 1890-1940 (Lincoln: University of Nebraska Press, 1995); Marcela Nari, Politicas de maternidad y maternalismo politico: Buenos Aires (1890-1940) (Buenos Aires: Biblos, 2005), and "Maternidad política y feminismo," in Historia de las mujeres en la Argentina, 2: Siglo XX, Fernanda Gil Lozano, Valeria Silvina Pita, and María Gabriela Ini, eds. (Buenos Aires: Taurus, 2000), 197-221; Marguerite Guzmán Bouvard, Revolutionizing Motherhood: The Mothers of the Plaza de Mayo (Wilmington, DE: Scholarly Resources, 1993); Donna J. Guy, White Slavery and Mothers Alive and Dead: The Troubled Meeting of Sex, Gender, Public Health, and Progress in Latin America (Lincoln: University of Nebraska Press, 2000); Graciela Sapriza, "Historia reciente de un sujeto con historia," Revista Encuentros (Montevideo) 7 (July 2001): 87-105; and Pieper Mooney, Politics of Motherhood. Also see Maxine Molyneux, "Twentieth-Century State Formations in Latin America," in Hidden Histories of Gender and the State in Latin America, Elizabeth Dore and Maxine Molyneux, eds. (Durham: Duke University Press, 2000), 44-45; Dora Barrancos, "Maternalismo," 205-206; and Graciela Di Marco, "Maternidad social," 211-213, in Diccionario de estudios de género y feminismos," Susana B. Gamba, ed. (Buenos Aires: Biblos, 2007). I thank Celia Gónzalez Venable and Jadwiga E. Pieper Mooney for their insights.

16. Most notably in Sandra McGee Deutsch, "The Visible and Invisible Liga Patriótica Argentina, 19191928: Gender Roles and the Right Wing," Hispanic American Historical Review 64:2 (May 1984): 233-258; "What Difference Does Gender Make? The Extreme Right in the ABC Countries in the Era of Fascism," Estudios Interdisciplinarios de América Latina y el Caribe 8:2 (July-December 1997): 5-21; "Spreading Right-Wing Patriotism, Femininity, and Morality: Women in Argentina, Brazil, and Chile, 1900-1940," in Radical Women in Latin America: Left and Right, Victoria González and Karen Kampwirth, eds. (University Park: Pennsylvania State University Press, 2001), 223-248; and "Spartan Mothers: Fascist Women in Brazil in the 1930s," in Right-Wing Women: From Conservatives to Extremists Around the World, Paola Bacchetta and Margaret Power, eds. (New York: Routledge, 2002), $155-167$. 
reveals both maternalist and non-maternalist appeals to action and motives for participation. ${ }^{17}$

\section{LA Liga Argentina POR los Derechos Del HOMBRE}

Formed in 1920, the young Partido Comunista Argentina (PCA) faced hardship in the 1930s and early 1940s. General José F. Uriburu overthrew President Hipólito Yrigoyen (1916-22, 1928-30) of the democratic centrist Unión Cívica Radical party, ending Argentina's short-lived electoral democracy and inaugurating a 13-year period of fraudulent rule. The Uriburu regime (1930-32) imprisoned, tortured, and deported militants without trial and allied with the Nacionalistas, a coalition of extreme rightist groups that assaulted leftists and the Radicals. The PCA became a special target. While bills formally prohibiting the party in 1932 and 1936 did not pass, official and Nacionalista repression of Communists and other leftists continued. ${ }^{18}$ Nevertheless, these years witnessed the recruitment of women and men into Communist-led textile, garment, and other unions. Women also worked in solidarity with Communist prisoners.

Supporting political prisoners was a means of countering what leftists considered fascist oppression. Especially prominent was Socorro Rojo, the local affiliate of International Red Aid, founded by the Comintern in 1922 to help political detainees around the globe. A remarkable volume containing PCA records confiscated by the authorities describes women's involvement in the organization and in solidarity organizations founded later, including a Communist Party estimate that 1000 women had joined Socorro Rojo by around 1936. ${ }^{19}$ In 1937, this group expanded into what became known as the Liga Argentina por los Derechos del Hombre (or Liga). Men and women of differing political allegiances joined the Liga, but Communists set its course. The Liga was organized into two levels, one public-facing and the other operating more behind the scenes.

17. I have learned from the nuanced approaches offered by Michelle Chase, Revolution within the Revolution: Women and Gender Politics in Cuba, 1952-1962 (Chapel Hill: University of North Carolina Press, 2015); and Katherine M. Marino, "Transnational Pan-American Feminism: The Friendship of Bertha Lutz and Mary Wilhelmine Williams, 1926-1944," Journal of Women's History 26:2 (2014): 63-87. I have also learned from our conversations on this issue. See also Rosemblatt, Gendered Compromises; and Olcott, Revolutionary Women.

18. Among other works, see Sandra McGee Deutsch, Las derechas: The Extreme Right in Argentina, Brazil, and Chile, 1890-1939 (Stanford: Stanford University Press, 1999); Federico Finchelstein, The Ideological Origins of the Dirty War: Fascism, Populism, and Dictatorship in Twentieth Century Argentina (New York: Oxford University Press, 2014); and Camarero, A la conquista, xxxix, 157, 161-172.

19. H. Senado de la Nación, Represión del Comunismo. Proyecto de ley, informe y antecedentes por el senador Matías Sánchez Sorondo, Vol. 2: Antecedentes (Buenos Aires: H. Senado de la Nación, 1940), 207. 
Among women in the Liga's public layer were the Communist Fanny Edelman, the sympathizer Dalila Saslavsky, and Rosa Scheiner of the Partido Socialista Obrero, which was close to the PCA. This group gathered funds, provided legal aid, defended the moral values of freedom and democracy, and denounced fascism, human rights abuses, and anti-Semitism. ${ }^{20}$ The Liga also conducted less visible operations, helping the jailed and their families. Not surprisingly, women were more engaged in these maternalist-tinged duties than men and typically worked in the organization's foreign-language or ethnic sections. Gílenberg belonged to the Liga's Comisión Israelita Femenina. A lingerie maker who arrived in Buenos Aires in the early 1930s, she had been a Communist Party member in her native Poland; in Argentina, she was a "Communist without a membership card." She was active in Procor, which supported the Soviet autonomous Jewish region of Birobidzhan and solidarity with the Spanish Republic. Her husband described her as a strong militant, "very energetic and very dynamic . . . and very brava" (fierce). In our interview, she spoke fondly of the women in her "army" and those whom she had aided. Unlike some of her compañeras, Gílenberg did not join the Liga to aid jailed relatives; her activism stemmed from her sense of comradeship and her identification with the diasporic militant trajectory. ${ }^{21}$

Gílenberg and the other working-class Communist women in this semiclandestine level of the Liga incurred great risk of being arrested. The legendary solidarity figure, "La Vieja," Zlate Dlugates, the mother of inmates, was detained several times. She boldly resisted guards who tried to prevent her from entering the jail with the many packages she carried for prisoners, so she claimed that they were not only for her sons but also for fictitious grandsons. Indeed, danger marked the entire process of solidarity, starting with the police interviews that would begin soon after an arrest. Sometimes these conversations took place at the dreaded Sección Especial, the agency responsible for torture. Upon hearing of an arrest, the women met with the prisoner's family and spread the news throughout the militant's neighborhood, workplace, and union, collecting money, recruiting for the Liga, and tying this episode to the broader political struggle. They gathered food, and prepared and carried it to the prisoners and washed their clothes. They sent provisions to those

20. On International Red Aid and the Liga, see Socorro Rojo, May 1, 1932, 2; Sandra McGee Deutsch, Crossing Borders, Claiming a Nation: A History of Argentine Jewish Women, 1880-1955 (Durham: Duke University Press, 2010), 192-195; J. Martin Ryle, "International Red Aid and Comintern Strategy, 1922-1926," International Review of Social History 15:1 (April 1970): 43-68; Fanny Edelman, Banderas, pasiones, camaradas (Buenos Aires: Dirple, 1996), 2428; and Franco, Mujeres, 19.

21. Gílenberg, interview. Her husband's interview appears in Sara Itzigsohn, et al., Integración y marginalidad. Historias de vidas de inmigrantes judios en la Argentina, 2nd. ed. (Buenos Aires: Pardés, 1985), 256. See also Berta Baumkoler, La lucha es vida (Buenos Aires: Carlos A. Firpo SRL, 2000), 26-27. I did not find a complete membership list for the Liga or any of the other movements under study. 
incarcerated in far-off penitentiaries. These perilous acts cemented friendships among solidarity workers, the jailed, and families, and built ties among activists, who helped each other cope with fear. ${ }^{22}$ A renowned Communist writer, Raúl González Tuñón, dedicated a poem to the women of solidarity. In it he praised the "novia constante, madre obvera,/agente de la vida, fundadora del mundo,/ .. Contra el odio y la guerra defenderá su cría, contra la larga sombra erguirá su bravura/ y en el amor será la flor de la ternura/ azucena sembrada con luz su corazón." ${ }^{23}$ Some women did in fact enter the Liga to care for their loved ones, but the main inspiration for Gílenberg, and surely for others, was not maternalist. In Dlugates's case, militancy may have preceded her solidarity work and influenced her children to join the party.

Another activist of Polish Jewish origin entered the PCA before she engaged in solidarity. Berta Baumkoler was enthralled with the revolutionary ideas of her future spouse, Mendel, a Communist Party member. Mendel asserted that capitalism reduced women to private property that was bought and sold. Genuine change was impossible without altering women's status, he claimed, and such concepts helped to win her over. A constant refrain in her memoir was that the couple had subordinated their love to the revolutionary cause, which came before all else. Even after Mendel was deported and the couple later reunited in the Spanish Republic, they kept their feelings in check; like other militants, they did not want to feel emotionally vulnerable. After an early miscarriage Berta did not get pregnant again for a while. Some said it was time to work for the revolution, which appeared imminent, rather than have a family. A few years later she had a son, Vladimiro, whom she took everywhere. "I tried to reconcile my maternity with the activities of the Party," she recalled. Baumkoler attributed her solidarity work to her desire to help not only her frequently imprisoned husband but other militants as well. Love and ideological commitment bound the couple, whose shared political aims set the tone for much of Berta's life. ${ }^{24}$ Baumkoler suppressed some of her intimate and maternal sentiments in favor of revolution. Motherhood was important to her, but it did not motivate or justify her politics.

Regarding the non-militants who entered the Liga, one senses that as their experience, camaraderie, and sense of empowerment grew, so did their political consciousness. This was precisely one of the Liga's goals. It seems plausible that laying the groundwork for a future classless society—solidarity's "eminently

22. Jeff Goodwin, James M. Jasper, and Francesca Polletta, "Introduction: Why Emotions Matter," in Passionate Politics: Emotions and Social Movements, Goodwin Jasper, and Polletta, eds. (Chicago: University of Chicago Press, 2001), 19. Also see Gílenberg, interview; and Socorro Rojo, May 1, 1932, 7.

23. Quoted in Edelman, Banderas, 26. I have kept the original Spanish to retain the poetic quality.

24. Baumkoler, La lucha, 21-22, 26, 30, 34, 55, 63. 
revolutionary task," as Edelman put it - gradually overtook their commitments to caregiving and familial duty. ${ }^{25}$ Or perhaps these aims melded together.

Zlate Dlugates and another "vieja," Carolina Molessini, stood out for their courage in facing hostile prison officials and the Sección Especial. For Edelman, they represented "the highest expression of the thousands of women who made solidarity an objective of life." 26 Dlugates, Molessini, Gílenberg, and the other women of the Liga's "hidden" level epitomized all the elements of solidarity I have mentioned. The army of women stood for equality within the ranks, an end to injustice, and, at least implicitly, women's right to engage in political action as a hallmark of citizenship. The frequent persecution of leftists since the 1930s explains why the Liga still exists.

\section{The Popular Front and The Agrupación Femenina ANTIGUERRERA}

The magnitude of repression during the 1930s and 1940s forced Communists to operate largely through broad semi-independent groups that could function more or less openly, such as the Liga. Another such organization was the Agrupación Femenina Antiguerrera. While the Chaco War (1932-35) between Paraguay and Bolivia prompted its formation, a new Comintern policy was critical in shaping it. Catalyzed by the Japanese invasion of Manchuria, European pacifists and leftists, including Communists, organized a conference against imperialist war in Amsterdam in 1932. Calling itself the World Committee against War and Fascism, the Amsterdam contingent congregated anew in Pleyel Hall in Paris in 1933, after Hitler became the German chancellor. The growing Nazi threat also spurred Communists to cooperate with other antifascists, heralded by what was called the Amsterdam-Pleyel movement. Georgi Dimitrov, head of the Comintern and secretary general of the World Committee, announced this Popular Front strategy at the Comintern's Seventh Congress in 1935. ${ }^{27}$ Dimitrov's speech received much attention in PCA circles; so too, apparently, did his comments on women. The Comintern leader scolded his comrades for paying women insufficient notice, insisting that the participation of the masses of women was vital to fight fascism and war

25. Edelman, Banderas, 25. According to Hatzky and Mor, "Transnational Solidarities," 132, "solidarity meant the road to a classless, Communist society."

26. Edelman, Banderas, 25-26.

27. David James Fisher, Romain Rolland and the Politics of Intellectual Engagement (Berkeley: University of California Press, 1988), 147-170; Larry Ceplair, Under the Shadow of War: Fascism, Antifascism, and Marxists, 19181939 (New York, Columbia University Press, 1987), 78-93. On antifascist coalitions in France and Argentina before Amsterdam-Pleyel, see Ricardo Pasolini, Los marxistas liberales. Antifascismo y cultura comunista en la Argentina del siglo XX (Buenos Aires: Sudamericana, 2013), 29-32, 35-37. 
effectively. It was essential, he argued, to convoke Communist women, along with existing women's antiwar, antifascist, progressive, and social democratic groups, in the Popular Front. ${ }^{28}$

In the meantime, the World Committee of Women against War and Fascism arose within the Amsterdam-Pleyel movement. In 1934, the committee invited women across the globe to a congress in Paris, aimed at linking peace activism with women's political and economic liberation. The 1,200 women from Europe, the Americas, and Asia who attended the meeting held different political beliefs, but the Communist influence was pervasive. ${ }^{29}$ The press and several prominent women spread news of the conference in Argentina, even though no Argentines attended. A socialist, feminist, and pacifist who bridged the Río de la Plata, Paulina Luisi served as the Uruguayan delegate on the World Committee throughout the 1930s and signed its original manifesto. She discussed the meeting and antifascism with Argentine intellectuals and activists, including the Unión Argentina de Mujeres (discussed in subsequent paragraphs). ${ }^{30}$ Dr. Nydia Lamarque, a Communist lawyer and writer, spoke in several cities on Amsterdam-Pleyel and the women's congress. Lamarque headed the Comité Argentino Antiguerrero and helped organize a Communistsponsored conference against imperialist war in Montevideo in 1933. ${ }^{31}$

The Agrupación Femenina Antiguerrera (AFA) arose in this context. Founded in January 1935, AFA was the "most serious" women's movement tied to the Communist Party at that time, with the "most politically active" women, according to Communist leaders. It was among the women's associations they described as "oriented, controlled or influenced by the Party." 32 By 1936,

28. Senado, Represión, Vol. 2, esp. 99-100.

29. Manifesto in El Ideal (Montevideo), July 4, 1934, clipping, n.p., no. 4, Serie Italia, Sección Nazi-Fascismo, Caja 1, Subfondo P. Luisi, Fondo Centro Republicano Español, Facultad de Humanidades y Ciencias de la Educación, Universidad de la República, Montevideo, Uruguay; Congreso Internacional de Mujeres contra la Guerra y el Fascismo, Paris, 1934, no. 19, Carpeta 5, Caja 256, Archivo Paulina Luisi, Archivo General de la Nación [hereafter AGN], Montevideo, Uruguay. See also, among other sources, Emmanuelle Carle, "Women, Anti-Fascism and Peace in Interwar France: Gabrielle Duchêne's Itinerary," French History 18:3 (2004): 306-308; Lorraine Coons, "Gabrielle Duchêne: Feminist, Pacifist, Reluctant Bourgeoise," Peace \& Change 24:2 (April 1999): 128-129, 131-132; and Siân Reynolds, France Between the Wars: Gender of Politics (London: Routledge, 1996), 195-199.

30. See for example her address to the Unión Argentina de Mujeres, in La Vanguardia, October 30, 1938, and La Razón, October 19, 1938, clippings, Carpeta 1936-1938, Colección Paulina Luisi, Archivo Literario, Departamento de Investigaciones, Biblioteca Nacional, Montevideo, Uruguay; and Paulina Luisi to Gregorio Bermann and Deodoro Roca, June 7, 1935, no. 5, Carpeta 7, Caja 252, Archivo Paulina Luisi, AGN. On Luisi, see Christine Ehrick, The Shield of the Weak: Feminism and the State in Uruguay, 1903-1933 (Albuquerque: University of New Mexico Press, 2005), and Radio and the Gendered Soundscape: Women and Broadcasting in Argentina and Uruguay (Cambridge: Cambridge University Press, 2015); and Graciela Sapriza, Memorias de rebeldía. Siete historias de vida (Montevideo: Puntosur, 1988), 79-107. See also Frente Único (Córdoba), December 1935, 23.

31. Introducción, Centro de Documentación e Investigación de la Cultura de las Izquierdas en Argentina (CeDInCI), microfilm roll 6; Boletín del Comité Organizador del Congreso Antiguerrero Latinoamericano, December 15, 1932, 4; and Juventud Antifascista (Rosario), December 15, 1934.

32. Senado, Represión, Vol. 2, 207. 
the AFA had approximately 3,000 to 4,000 members, who were grouped in chapters in the federal capital, Buenos Aires province, Córdoba, and Tucumán (and perhaps other locations), along with loosely affiliated associations in Córdoba, Mendoza, and Rosario. The AFA was particularly active in the province of Córdoba. In its capital women formed neighborhood committees, organized protests against the Italian invasion of Ethiopia, and hosted lectures by intellectuals and political figures. The incipient organization, however, faced several challenges: the chapters and affiliates had not united into a solid national organization, and members' visible connections to the Communists drew police harassment. ${ }^{33}$

Strongly influenced by the World Committee of Women against War and Fascism, AFA members, who described themselves as "workers, employees, students, teachers, professionals, intellectuals, and housewives," invited all women to join their campaign for a ceasefire in the Chaco. Clearly, the AFA did not regard women simply as mothers; it placed housewives at the end of the list. Its goals included disarmament, reduced military service, the redirection of military expenditures into cultural and social projects, an end to militaristic education, and freedom for those imprisoned for antiwar beliefs. Women of varied political persuasions, including Socialists and anarchists, responded to its call. ${ }^{34}$

The title of a 1936 AFA pamphlet, La mujer argentina y sus derechos, along with the large numbers of women speakers at the organization's meetings, also indicated a concern for gender equity. In one such speech delivered in Córdoba, the Socialist Leonilda Barrancos discussed the situation of Argentine women. We do not have a record of what she said, but we do have an idea of how some in Córdoba perceived the women orators and activists. Flecha, a voice of the local peace movement, considered the presence of AFA barrio committee members at the podium a "new and flattering feat for the Cordobesa woman" and praised the organization's work of "cultural emancipation," finding it more "lively" and active than that of men. ${ }^{35}$

The AFA denounced imperialism for promoting war and for its negative effect on women. It accused US and British firms of using the Chaco conflict to

33. Senado, Represión, Vol. 2: 206-207 (quotes), 210; Agrupación Femenina Antiguerrera, La mujer argentina y sus derechos. A la paz, al trabajo, a la cultura (Buenos Aires: Agrupación Femenina Antiguerrera, 1936), 12; Flecha (Córdoba), November 2, 1935, 4; November 14, 1935, 4; and December 30, 1935, 5.

34. Telma Reca to Heloise Brainerd, January 30, 1936, and attached Agrupación Femenina Antiguerrera manifesto, n.d., (quote), Women's International League for Peace and Freedom (WILPF), Part 3: US Section, A4, Part 1, Box 22, Folder Correspondence of Brainerd with Persons in Argentina, 1934-1936, DG 043, Swarthmore College Peace Collection (SCPC). Also see Franco, Mujeres, 16-18; and iMujeres! Órgano de la Agrupación Femenina Antiguerrera, May 1937, n.p.

35. Flecha, November 14, 1935, 4; December 30, 1935, 5. 
appropriate the region's oil and argued that the domination of these two countries kept Argentina from developing according to its own people's wishes. In turn, Argentina's dependent status damaged women by reinforcing their subordination to men. While they had to work outside the home to support their families, economic underdevelopment limited their opportunities and increased their reliance on men's salaries. ${ }^{36}$ The AFA's discussion of the effects of fascism on women further underlined its preoccupation with their status. Fascism was the "most immediate generator of wars." 37 It terrorized its own people and incited nationalist resentments. Having expelled women from professional, government, and industrial employment, fascism converted them into machine-like bearers of future soldiers. It imprisoned women in the home and men on the battlefield. In these statements, the AFA was implying a strong criticism of the confinement of women to household duties in Argentina, as well as in Europe. In Italy, Mussolini's reduction of wages was jeopardizing working-class families. To halt this regressive, bellicose, and misogynist movement in Argentina, the AFA demanded the suppression of the fascist-leaning Nacionalista militias.

The AFA wove maternalism into its response to warfare. Armed conflicts resulted in hunger, rising prices, unemployment, the spread of disease, and the dissolution of families, all of which imperiled women's mission. The organization exhorted Argentine mothers to express solidarity with suffering women and children in combatant countries. By teaching their sons that love transcends boundaries, women could prevent them from becoming soldiers: "Mothers! We who give life will not permit it to be destroyed!" 38 Yet, the upper-class Communist intellectual María Rosa Oliver obliquely challenged these maternalist arguments. A speaker at AFA events, she was emerging as a significant figure in the incipient Popular Front women's solidarity movement. Oliver argued that the schools and radical rightist Nacionalistas were spreading militaristic propaganda to prepare people psychologically for war. The reign of foreign capital and the suppression of popular expression and honest elections made it even easier to push Argentina into combat. Fascists claimed it was as natural for men to die in battle as for women to give birth, and some women on both sides of the Atlantic seemed to accept this notion, obeying with submission their apparent biological mandate to produce cannon fodder. Like men, they too had raised their hands in the fascist salute.

36. On this and the next few paragraphs, see Agrupación manifesto, and Agrupación, La mujer argentina. See also Franco, Mujeres, 16-18; and ¡Mujeres!, May 1937, n.p.

37. Agrupación manifesto.

38. Agrupación manifesto. 
In contrast, declared Oliver, we women of the Americas (referring to antiwar leftists) are issuing a call for peace. ${ }^{39}$ Was she criticizing fascist women for melding motherhood to war and suggesting that true mothers, such as those in the Western Hemisphere, were pacifists? Or did she reject such biological imperatives? In fact she did spurn such imperatives, at least for herself. In her autobiography, Oliver described how as a girl she had distanced herself from women's "natural" attributes and the social expectations imposed by her class and gender. Her physical condition and her mother's reaction to it helped determine Oliver's attitudes. After contracting polio at the age of ten, she was confined to a wheelchair. Due to her disability, her mother did not include her in discussions of boyfriends, nuptials, or maternity, nor did she present her at social gatherings as eligible for marriage. Oliver's isolation from such matters apparently did not trouble her, although her mother's over-protectiveness did. A doctor informed Oliver that she could have children, but she did not want them. She created a feminine identity that was disconnected from maternity and transcended class and gender stereotypes. Her father's openness encouraged her to question patriarchal limits and participate in activities outside her home and country. ${ }^{40}$ Oliver's life centered on writing, leftist politics, and the friendships she formed in those circles.

Rosa Scheiner, an AFA officer, contested maternalism more publicly and forcefully. A dental surgeon, Socialist, and activist in the Centro Socialista Femenino, Scheiner contributed to the party newspaper La Vanguardia in the early 1930s. Writing from a strong Marxist perspective, she frequently addressed women's issues, arguing that women's biological role had given men a pretext for locking them up in the home. By pushing women into the labor force and collective life, capitalism had liberated them from their domestic jails and given them greater economic independence, but the double or triple roles they played each day still shackled them. They needed full political rights to build a new social order that would truly emancipate both women and men. Conservative forces mounted defenses against this revolutionary threat; the Church and the elite, for examples, deployed the usual argument of women's maternal mission to deny them the vote. Yet many women had no children, and numbers of those who did spent only a portion of their lives nursing and raising them. Women who were well-off or worked outside the household handed their

39. ¡Mujeres!, April 1937, n.p. On Oliver and her Communist militancy, see Waldo Frank to Oliver, August 3 , 1937, Box 3, Folder 50, María Rosa Oliver Papers, CO829, Princeton University Library, Department of Rare Books and Special Collections; and Horacio Tarcus, ed., Diccionario biográfico de la izquierda argentina. De los anarquistas a la "nueva izquierda" (1870-1976) (Buenos Aires: Emecé, 2007), 464-465.

40. Marina Becerra, "Maternidad y ciudadanía en la Argentina de principios del siglo XX: un análisis de la autobiografía de María Rosa Oliver," Contracorriente 10:2 (Winter 2013): 202-218; María Rosa Oliver, Mundo, mi casa (Buenos Aires: Ediciones de La Flor, 1995), and La vida cotidiana (Buenos Aires: Sudamericana, 1969). 
children over to hired help or schools for care. ${ }^{41}$ Scheiner defied convention by decoupling women from motherhood and hinting that in the future women's public pursuits would - even should - outweigh their domestic ones.

By 1937 Scheiner had entered into a leftist Socialist schism that tilted toward Communism, the Socialist Workers party (PSO), and she became the secretary general of the PSO's Comisión Femenina. She continued to analyze women and politics from a Marxist standpoint in articles in the PSO periodical Avance, and at the same time continued her activism in AFA. Avance also printed a speech she delivered in 1937 to the Federación Argentina de Mujeres por la Paz, to which AFA and other women's peace groups belonged. The speech was a response to right-wing attempts to divest married women of their rights, as I discuss in subsequent paragraphs. Divisions among women notwithstanding, Scheiner noted that they united around peace. To end war, women needed to make their voices heard, and this meant attaining suffrage. As women defended and fought to extend their rights, they would join a larger struggle for democracy in Argentina. Democracy could not provide true equality for women, but only in such a climate could women work effectively for their emancipation. Like María Rosa Oliver, Scheiner decried fascists' use of women as producers of cannon fodder, but she also criticized fascism for converting women into men's property. ${ }^{42}$ Even as she gave a nod to maternalism by denouncing fascist perversions of women's reproductive roles, she attacked gender boundaries.

Following the ideas of Oliver, Scheiner, and the Women's World Committee, the AFA saw women's struggles against imperialism, war, and gender subordination as intertwined. Women workers required an eight-hour day, enforcement and expansion of labor and maternity legislation, higher salaries, childcare facilities, and the prevention of sexual abuse. Poor working conditions, low salaries, and limited freedoms plagued teachers, and the lack of education and a minimum wage hurt rural women. Male domination inside and outside the home hurt even privileged urban women. Exacerbated by colonialism, this harmful situation for women-as mothers,

41. La Vanguardia, August 16, 1932, 8; February 13, 1933, 10; February 27, 1933, 8; and February 23, 1934, 12. Also see Deutsch, Crossing Borders, 161-162. Scheiner's position in the AFA is mentioned in Conferencia Argentina por la Paz, flyer, 1936, Exp. 801-36, Vs. 82, Sociedad Israelita de Protección a Niñas y Mujeres, "Ezras Noschim" collection, CAHJP-INV 4349, Central Archive for the History of the Jewish People, Jerusalem. This collection has been recatalogued since I used it in 2001.

42. Avance, November 18, 1937, 3 (speech), November 25, 1937, 5; Federación Argentina de Mujeres por la Paz folder, Argentine Collective Box, SCPC. On the origins of the PSO see Ilana Martínez, “'Por la vuelta a Marx': el ala de izquierda del PSA, 1929-1935" (MA thesis, Universidad Nacional de General San Martín, 2012); and Pablo Lacoste, El socialismo en Mendoza y en la Argentina, 2 vols. (Buenos Aires: Centro Editor de América Latina, 1993). 
workers, and professionals - and their families would only worsen under fascism. ${ }^{43}$

The AFA's notions of motherhood and caregiving resonated with many women. Protecting children, providing for families, sympathizing with women and children in warring nations, and spreading the ethical values inherent in maintaining life permeated much of its solidarity. The Spanish Civil War clarified the gendered ethical rift between the AFA and fascist imperialism. The German and Italian bombing of Guernica in 1937 demonstrated to the organization that this conflict pitted those who fought for morality, dignity, culture, and freedom against those who had lost all vestiges of humanity. However, the AFA was not uniformly maternalist. Although its demands for women's rights underlined their need to support their families, they also sought to strengthen women's roles outside the home. ${ }^{44}$ Furthermore, Scheiner's calls (and perhaps those of other members) for women to fight for democracy and their prerogatives were devoid of maternalist justifications. The AFA's engagement in this struggle evokes Gílenberg's army of women, if one can apply such a phrase to a peace movement. Enthusiastic, dedicated, well-organized, and stalwart in the face of repression, its soldiers claimed citizenship through their words and deeds. ${ }^{45}$ In fact, this was a revolutionary army in the making-the AFA's resistance to imperialism, fascism, capitalism, women's subordination, and all forms of domination bespoke a radical consciousness. The movement built upon notions of women's inherent difference from men, yet also transcended them.

The AFA fit various definitions of a solidarity movement. It fought multiple injustices and their effects on women and families. Members forged ethical bonds with far-off victims of war and contested the structures that perpetuated inequality. The organization built bridges between its adherents of diverse political and social backgrounds and seems to have established trust and good relations among them, particularly at the neighborhood level. Confrontations with authorities galvanized mutual support and cohesion within its ranks. Its resistance to repression and defiant rhetoric highlighting the threat to women's roles, old and new, demonstrated empowerment. In 1936, the AFA invited its affiliates and other groups to a women's peace congress in Buenos Aires in November 1936. The police disrupted the meeting, which nonetheless forged a national movement, the Federación Argentina de Mujeres por la Paz. By the late 1930s, however, the Federación faded, as did the AFA. ${ }^{46}$ The possible

43. Agrupación, La mujer argentina, 5-7.

44. iMujeres!, April 1937, n.p.

45. Reca to Brainerd, January 30, 1936, WILPF, SCPC, noted their enthusiasm. See also Franco, Mujeres, 18.

46. Pueblo F (place unknown), November 1936, Box 4, Folder Clippings from Latin American Papers, 19351950 (continuation 2), and Box 5, Folder Press Clippings 1935-1949 (continuation 3), People's Mandate Committee 
causes are the onset of World War II, tensions surrounding the Soviet Union's initial neutrality, and the AFA's shift away from the Popular Front policy. Nevertheless, some AFA members would reappear in future solidarity groups.

\section{The SPANISH CIVIL WAR}

The declaration of the Spanish Republic in the 1930s energized María Rosa Oliver and many other Argentine progressives. The plight of a motherland that had freed itself from tyranny and created a progressive government, only to fall prey to a right-wing revolt, reminded Argentines of their own experience of the short-lived democracy that had ended with the revolution of $1930 .{ }^{47}$ Years later, Oliver recalled that the Spanish Civil War (1936-39) instilled in her cohorts a new fervor, one of solidarity with a distant people fighting for their rights. ${ }^{48}$ Italian and German backing for the rebels reinforced the threat of fascist aggression and convinced unprecedented numbers of women and men of many backgrounds to embrace the pro-Republican and antifascist cause. According to Oliver, the Republic struggled for everything her generation believed in, and its members thought their future depended on its destiny. Fearing that the conflict would halt revolution throughout the world, they extended their full support to the Republicans. Oliver's Communist ideals impelled her to act; she and other intellectuals, including Spanish exiles, organized benefits and gathered supplies. The repression and other difficulties that she and her male and female colleagues faced made them work harder. Often they sang together to keep up their spirits, and stirring tunes from the Spanish front probably formed part of their repertoire. The act of singing calmed political arguments, created bonds, and helped the movement cope with fear and frustration. Oliver never again sang as much or as enthusiastically. ${ }^{49}$

Fanny Edelman's autobiography helps explain her involvement. She imbibed the poverty, empathy with workers, and love of culture of her proletarian Jewish immigrant milieu. Aware of her concern for social issues, her future husband Bernardo encouraged her to join the Communist Party, which she did in 1934,

Records, DG 109, Series A, SCPC; Conferencia Resolutions, Box 63, Folder 2, and assorted documents in Box 63 , Folder 3, IACW, A, Doris Stevens Papers, Schlesinger Library, Harvard University (SLHU); Córdoba, November 16, 1937, 3; ;Mujeres!, April 1937, n.p.; AFA to Ezras Noschim, September 1936, exp. 801-36, Vs. 82, CAHJP-INV 4349.

47. Rein, "Transnational Struggle," 173.

48. María Rosa Oliver, "Queridas amigas, mujeres de España,” n.d., Box 1, Folder 44, Oliver Papers, Princeton.

49. Oliver, "Queridas amigas”; María Rosa Oliver, Mi fe es el hombre (Buenos Aires: Carlos Lohlé, 1981), 7, 11-12, 35, and interview with Leandro Gutiérrez, 1971, 43, Instituto Torcuato Di Tella, Proyecto de Historia Oral, Universidad Torcuato Di Tella, Buenos Aires. In Mi fe, 11-12, Oliver did not specify what they sang, but on page 35 she recalled that later, after the Republican defeat, singing songs from the Spanish front rekindled feelings of solidarity among Spanish exiles and Argentine sympathizers. 
when she began to participate in Socorro Rojo and the Liga. Bernardo shifted his allegiance from the Socialist party, alienated by its reformism, and followed suit. A lawyer, he defended Fanny and other Communists when they were imprisoned. They married in 1936, had two children, and shared many goals. They traveled to Spain a year after their wedding, and Fanny later reminisced about how she and her husband "tilted passionately toward the movement of solidarity with Spain, which stirred up the massive adhesion of our people." In Argentina, she served as officer of the Communist-aligned Comite Argentino de Mujeres Pro Huérfanos Españoles (CAMHE), and in Spain she continued working for International Red Aid. Some years after the couple's return to Argentina, an accident confined her husband to a wheelchair, which he used for the rest of his life. Fanny regretted that his disability and her militancy kept her from cultivating a close relationship with her children. Distance from one's children does not necessarily contradict a belief in maternalism, but it showed her priorities. The party, along with Bernardo's comradeship, was her compass. $^{50}$

A diverse Popular Front group, CAMHE was among the largest organizations in solidarity with the Spanish Republic. Curiously, what Edelman described as the first mass political organization of women in Argentina has received little attention. ${ }^{51}$ Its ties to Communism were evident in Buenos Aires but less so in some areas of the interior, where the party was weak and Socialism and other political persuasions may have predominated. Maternalism pervaded CAMHE's tasks and entreaties. Its 150 branches sent goods to the children of slain Republican soldiers and sponsored facilities for them. ${ }^{52}$ A newspaper in Bahía Blanca claimed that the local chapter summoned "those maternal sentiments that every woman shelters in her heart." ${ }^{53}$ Responding to the plea of the Spanish Communist Isidora Dolores Ibárruri Gómez ("La Pasionaria”), CAMHE members prepared 5000 sets of baby garments and dispatched them to Barcelona. According to Edelman, this campaign represented "labor filled with the love and tenderness of thousands of women." CAMHE members injected affection into their care for Spanish infants and the bonds they formed with women of their network. ${ }^{54}$ As had the Liga, the organization practiced a

50. Edelman, Banderas, 17-24, 31-34 (quote on 34), 45-53, and elsewhere.

51. Casas, "Las mujeres," briefly describes CAMHE but relies almost completely on Edelman's account. Eleonora Ardanaz's PhD dissertation on antifascism in Bahía Blanca (in progress) should fill some of this gap, as previewed in "Maternalismo."

52. Eleonora Ardanaz, communication; Edelman, Banderas (February 17, 2016), 46.

53. Quoted in Ardanaz, "Maternalismo," 15.

54. Edelman, Banderas, 46-47; Casas, "La guerra," 70-72, 78-79. Edelman's phrase reminds us of Jocelyn Olcott's point that scholars should not separate love from their analyses of reproductive labor. See "Introduction: Researching and Rethinking the Labors of Love," Hispanic American Historical Review, special issue on Labors of Love: Production and Reproduction in Latin American History, 91:1 (February 2011): 2, 5-6. 
motherly, hands-on style of solidarity that invested women and helped them imagine and feel close to their recipients.

Although CAMHE recruited and worked in customary gendered ways, its goals were anything but conventional. Through sewing and knitting, leftist politics and class consciousness entered its adherents' minds and households and remained there, as journalist Clara del Franco observed. Participation in CAMHE and the Spanish Republican solidarity movement ushered many into the party and a host of progressive groups and causes. ${ }^{55}$ CAMHE activities supported a revolutionary Spanish government that, albeit temporarily, instituted democracy, curbed the Catholic Church, set land reform into motion, and incorporated workers, peasants, and women into the political system, with all the changes these measures implied for women's roles. Maternalism initially may have beckoned to numerous women, but once they entered this movement it is likely that they acquired political convictions that diverged from this belief.

Oliver's remembrances demonstrated the mutuality, cohesion, and moral support that characterize solidarity. Women's experiences of sewing and knitting around the table in homes and CAMHE workshops reinforced such traits. A shared sense of motherhood may have further bridged distinctions among many CAMHE members; for others, revolutionary ideals served this purpose. All the members sought to fight the injustice of the civil war, help its victims, and create a better world. In the process they challenged fascism, capitalism, and inequality and promoted women's citizenship in Argentina as well as Spain. CAMHE was a large army of women wielding needles as their weapons, and the same would be true for the pro-Allied Junta de la Victoria, as we will see in following paragraphs.

\section{ARGENTINE UNION OF WOMEN (UAM)}

The UAM was another group that Communist leaders characterized as "oriented, controlled or influenced by the party." Despite its members' bourgeois backgrounds, the PCA believed that its purpose was to promote the interests of all women. Democratic, broad in scope, averse to reaction and "clerical obscurantism," the UAM, in its own view, could evolve into a mass movement for women's liberation, with Communist Party guidance. ${ }^{56}$

55. Franco, Mujeres, 21, 23; Edelman, Banderas, 46.

56. Senado, Represión, Vol. 2: 207, 210-211. On the UAM, see Oliver, La vida, 321-322, 348-357; Mi fe, 42; and interview, 50-51. See also Valobra, "Formación," 138-142; Tulio Halperín Donghi, Son memorias (Buenos Aires: Siglo XXI, 2008), 80, and La república imposible: 1930-1945 (Buenos Aires: Ariel, 2004), 209-210; Verónica Giordano, Ciudadanas incapaces. La construcción de los derechos civiles de las mujeres en Argentina, Brasil, Chile y 
The organization arose in opposition to a bill that threatened to nullify the married women's rights specified in the Argentine civil code. Similar as it was to European fascist laws, this proposed measure outraged a small but diverse group of friends in Buenos Aires and led them to create the UAM in March 1936. Communists, Socialists, Radicals, and others joined this Popular Front group, which spread to like-minded women in Rosario and Santa Fe. Among them were cultural luminaries, teachers, and professionals. ${ }^{57}$ Its first president, the nonpartisan upper-class author Victoria Ocampo, urged women to be active inside and outside the home. This unconventional figure supported motherhood but did not have children herself, directing her energies toward writing, editing the review Sur, and cultivating friendships with intellectuals abroad. ${ }^{58}$

The proposed changes to the law prompted Marta Samatán, president of the UAM Santa Fe chapter and an educator, union leader, orator, writer, and contributor to Socialist and Communist periodicals, to contemplate women's beleaguered status. Elsewhere, she claimed, men paid attention to women's ideas and wishes, but not in Argentina, a situation she largely blamed on women themselves. Many women, she noted, regard themselves as inferior beings, accepting their ignorance and dependency on men; it was up to women to change the false concept they had of themselves. "We should read, study, and debate more," but intelligently, deeply, critically. "It is necessary for us to learn to have a personality; to have ideas, in a word, to think. We women should think, we should say what we think and we should affirm our thinking." ${ }^{59}$ Years later, Samatán added that UAM sought to "make of the woman a person, that is, acquire the same civil, political, and economic rights as the man."60

\footnotetext{
Uruguay en el siglo XX (Buenos Aires: Teseo, 2012), 157-163; Graciela Quierolo, "La década de 1930 a través de los escritos feministas de Victoria Ocampo," in Modernidad en otro tono. Escritura de mujeres latinoamericanas: 19201950, Alicia N. Salomone et al., eds. (Santiago, Chile: Cuarto Propio, 2004), 219-239; Isabella Cosse, "La lucha por los derechos femeninos: Victoria Ocampo y la Unión Argentina de Mujeres," Humanitas 34 (2008): 139-156; Doris Meyer, Victoria Ocampo: Against the Wind and the Tide (New York: George Braziller, 1979), 135-140; Dora Barrancos, Mujeres en la sociedad argentina: una historia de cinco siglos (Buenos Aires: Sudamericana, 2007), 174-175; and Lavrin, Women, 94, 282-283, 316.

57. The founding members of the Rosario chapter are listed in Sociedad Unión Argentina de Mujeres (Filial Rosario), Ministerio de Gobierno, Justicia y Culto, Mesa de Entradas y Salidas, Expediente 5066, 2-8, Archivo General de la Provincia de Santa Fe, Santa Fe (AGPSF). The names of some Santa Fe members are found in Anuario El Litoral (Santa Fe), January 1, 1937, n.d., n.p., and newspaper clippings in Carpeta Género, Archivo y Museo Histórico Marta Samatán [hereafter AMHMS], Santa Fe. My description of UAM members is based on Oliver, La vida, 350, archival research, and consultations with historians and archivists in Santa Fe.

58. Hammond, Women's Suffrage, 136.

59. For this and the next paragraph, see Vida Femenina, January 15, 1937, 38-39. On Samatán's life and writings, see Mariela Coudannes, "Tradición y cambio social en dos regiones de América del sur. Mujeres elquinas y santafesinas en la narrativa de Marta Samatán,” Sudhistoria 3 (July-December 2011): 1-22.
}

60. Gloria de Bertero, Quién es ella en Santa Fe (Buenos Aires: Palabra Gráfica, 1995), 509. 
But there were women who undermined this drive toward education and autonomy. A 12-year old student who was repeating the first grade for the fourth time told Samatán that her mother, who overburdened her with household tasks, thought she did not need to learn to read and write: after all, she was a girl. Samatán found it appalling that a mother would interrupt her daughter's studies in the name of "sacrosanct domestic labors," as she sarcastically dubbed them. She argued that these duties "should never become the woman's insolent petty tyrants; they should occupy part of her activities, but nothing more than a part. They never should constitute the supreme motive of her existence, as often occurs." This outspoken intellectual daringly contested maternalism and women's subordination in a conservative provincial milieu. The fact that men and women were increasingly sharing the breadwinning tasks gave her hope. Work outside the household would promote economic independence, which in turn could lead to genuine women's liberation, a liberation realized in the heart, not just written on paper. Samatán wondered if women were prepared to mount a "'unanimous, tenacious and intelligent' protest" to protect their rights. ${ }^{61}$

Now that politicians had threatened these rights, the moment had come to stand up to the test. In a somewhat maternalistic fashion, the UAM rose to the challenge, declaring itself to be a nonpartisan group, influenced by human solidarity and dedicated to uplifting women's consciousness. It would elevate women culturally and spiritually, help them develop their abilities, and seek their equality. It aimed to dignify and ameliorate the lives of wed and unwed mothers and female wage earners by demanding compliance with labor and maternity laws, and their expansion. The UAM would promote children's health and education and support peace and solidarity between nations. ${ }^{62}$ And, of course, it sought to halt the revision of the civil code.

The Buenos Aires branch set about meeting those goals. It investigated legislation and conditions for working women, a group in which it refreshingly included housewives and sex workers. It negotiated with political figures and hosted feminist thinkers such as Paulina Luisi, Victoria Ocampo, and Samatán. Members discussed women's issues in the press and other publications. In 1938 UAM brought together 35 groups in the Junta Pro Derechos Políticos de la Mujer to mobilize support for suffrage. The Junta Pro Derechos asked political parties to nominate women candidates and include women's rights and social welfare provisions in their platforms. Linking peace and maternalism

61. Vida Femenina, January 15, 1937, 39.

62. Sociedad Unión Argentina de Mujeres (Filial Rosario), exp. 5066, 17-19, AGPSF; newspaper clipping, n.d., Carpeta Género, AMHMS. 
to women's demands, as had the AFA, the UAM insisted that women required equal rights and citizenship duties to work effectively against war. ${ }^{63}$ The UAM and the Inter-American Commission of Women (IACW), which advised the Pan-American Union on women's legal status and promoted women's rights, used this argument to press the Inter-American Conference in Buenos Aires in December 1936 and the Eighth International Conference of American States in Lima in December 1938 to recognize these rights, with some success. ${ }^{64}$

Assisted by Edelman and other Communist members, the UAM contacted women workers. ${ }^{65}$ The Santa Fe chapter had strong ties with the teachers' union and hosted a free legal service for women, as well as some charitable ventures. ${ }^{66}$ The UAM distributed 20,000 flyers at the 1938 May Day demonstration in Buenos Aires to explain the proposed revision of the civil code. "Do we deserve this insult?" the flyer asked indignantly, adding that women's "economic and social contribution justified equality of rights" with men. ${ }^{67}$ The UAM's argument was not necessarily based in maternalism, although the appeals of the Junta Pro Derechos sometimes were. It told women laborers that by voting they could secure daycare facilities, school lunch programs, and better housing and wages. ${ }^{68}$ The UAM had particularly close relations with the Communistled Textile Workers' Union (UOT); the UOT's Feminine Commission hosted UAM speakers and sent representatives to UAM congresses. This collaboration kept the UAM informed on women's rights in the workplace and the UOT informed about fascism. Women textile workers accompanied UAM delegates to the antifascist Congreso de Democracias in Montevideo in 1939. ${ }^{69}$

As the 1930s wore on, the UAM's growing concerns about fascism led it to reach across national boundaries. Oliver, a UAM officer and eventual president, explained that the organization favored democracies, which tended to grant women rights, and rejected fascist governments, which tethered them to the home. The UAM urged women to extend solidarity to the Spanish Republic

63. "Declaración de la Mujer Argentina," December 16, 1936, Box 62, Folder 16, Stevens Papers, SLHU.

64. Marion Ivel Morgan to Doris Stevens, September 9, 1938, Box 61, Folder 1; Box 63, Folder 6; Box 75, Folder 9, Stevens Papers, SLHU. See also Victoria Ocampo, La mujer y sus derechos y sus responsabilidades (Buenos Aires: UAM, n.d.); and UAM, Boletín Informativo Año 1937, 1-3, 5; Box 61, Folder 8, Stevens Papers, SLHU; Oliver, La vida, 350; El Litoral (Santa Fe), April 2, 1938, n.p., clipping, Carpeta Género, AMHMS; Orientación, December 5, 1940, 6; Katherine M. Marino, "Marta Vergara, Popular-Front Pan American Feminism and the Transnational Struggle for Working Women's Rights in the 1930s," Gender \& History 26:3 (November 2014): 653-654; and History of the Inter-American Commission of Women (CIM), 1928-1997 (Washington, DC: CIM/OEA, 1999).

65. Oliver, interview, 51; Valobra, "Formación," 139.

66. Nuestra Idea (Santa Fe), November 1936, 4; August 1939, 4; July 1942, 16.

67. UAM, "La mujer que trabaja reclama," attached to Susana Larguía to Brainerd, May 2, 1938, Folder Correspondence of Brainerd with Persons in Argentina-Chile, 1937-1938, WILPF, Part 3: US Section, Series A4, Part 1, Box 22, DG043, SCPC.

68. El Mundo, October 7, 1938, n.p., clipping, in Box 61, Folder 4, Stevens Papers, SLHU.

69. Norando, "Relaciones," n.p. 
and its exiles. ${ }^{70}$ Speaking to a Spanish and Argentine radio audience in August 1936, at the beginning of the Spanish Civil War, Ocampo deemed it crucial to know what was happening to women in other countries, since the ramifications inevitably would spread throughout the world. She cited the Spanish diplomat and writer Salvador de Madariaga, who distinguished what he called "subjective solidarity," referring to "ideas and feelings," from the "objective solidarity" of "actions and vested interests," and saw the world crisis in terms of the lag of the former behind the latter." In response to Madariaga, the UAM president called for women around the world to unite "in a solidarity that is not only objective but subjective." 71

The UAM's brand of solidarity, however, mainly focused on uniting and uplifting Argentine women in a struggle for citizenship. The goal was to create a more just society by promoting gender equity and better conditions for the poor, especially impoverished women and their offspring. By expanding the category of workers to include homemakers and sex workers and broadening the conventional view of motherhood to accept unmarried women, it opposed structures that fostered discrimination and inequality. Nevertheless, the UAM did not recruit lower-class women as members and its members may not have related to them as equals. It was a small army without commoners, rather than the mass movement the PCA had intended. The UAM seemed to represent bourgeois women's initial foray across the social divide for purposes other than charity. It tried to build cross-class solidarity among women, although its degree of success was unclear. ${ }^{72}$ However, the UAM conformed to aspects of solidarity in other ways. Its boldness in presenting demands to prestigious diplomats and resisting attacks on women's prerogatives revealed its growing self-confidence and empowerment. The jeering, incomprehension, and even persecution that members faced from authorities, clerics, and other adversaries strengthened ties among them. The founders' practice of meeting in each other's homes also reinforced their mutual support and widening horizons. Oliver recalled that as "the problems that we debated put me in contact with a concrete reality, vaster than the personal or that of my surroundings, I left those meetings with an expanded soul." 73

Maternal feelings influenced UAM adherents, but so too did zeal for protecting and promoting their rights and recognition apart from any presumed gender

70. Oliver in Estampa, n.d., 9, clipping, in Box 9, Folder 18, Oliver Papers, Princeton; El Litoral, April 2, 1938, n.p., clipping, Carpeta Género, AMHMS; La Capital (Rosario), November 26, 1941, 15.

71. Victoria Ocampo, "Woman and Her Expression," in Victoria Ocampo: Writer, Feminist, Woman of the World, Patricia Owen Steiner, trans. and ed. (Albuquerque: University of New Mexico Press, 1999), 171.

72. Oliver, La vida, 351-357; El Litoral, April 2 and 18, 1938, n.p., clippings, Carpeta Género, AMHMS

73. Oliver, La vida, 351. 
difference. To accentuate women's accomplishments, the UAM planned an exposition to be called The Woman in National Life, in Buenos Aires in 1942. It sent questionnaires to prominent women throughout the country and requested documents and photographs on women's involvement in the arts, professions, workforce, labor unions, political and social activism, and sports. ${ }^{74}$ This exhibition' was intended to publicize women's achievements, forge new links among women throughout Argentina, and win sympathy for women's aspirations, but it never took place. In 1943, the military ousted Ramón S. Castillo (acting president, 1940-42, and president, 1942-43) and imposed a harsh dictatorship that lasted until 1946. Alienated by the UAM's progressive initiatives, its ties with lower-class women, and its campaign to prevent the revision of the civil code, the Nacionalista-influenced regime closed the group down in $1944 .^{75}$ Yet many of its members, along with their notions of citizenship, carried over to the Junta de la Victoria. Unlike the UAM, the Junta actively welcomed working-class women into its ranks.

\section{JUNTA DE LA VICTORIA}

The German-Soviet Non-Aggression Pact of 1939 derailed the Popular Front, as Communists shifted their efforts from forming antifascist coalitions to denouncing Western imperialism. The Popular Front strategy re-emerged, however, with the German invasion of the Soviet Union on June 22, 1941. That day, the Communist Party called upon Argentines to help the beleaguered Communist nation. This call also indicated the party's shift from antiimperialism to cooperation with Great Britain and the United States to defeat fascism. Edelman observed that the people "relived . . . the historic occasion of aid to Spain," and, as before, "we Communists were . . in the front rows of that strong movement of solidarity" that covered much of the country. ${ }^{76}$ The German invasion and Party directives led two Communists, María Rosa Oliver and Cora Ratto de Sadosky, to create a women's group to help the Allies and save the Soviet Union. First, they recruited their friends from the Spanish solidarity movement and the UAM, and then they convened a spectrum of women along the lines of the Popular Front. They adopted as their emblem Winston Churchill's V for victory: hence the name Junta de la Victoria (the Junta). ${ }^{77}$ Appealing to domesticity, the Junta's first campaign was to knit 20,000 garments for British and Russian soldiers. ${ }^{78}$

74. Estampa Chaqueña (Resistencia), November 29 to December 6, 1941, 15-16.

75. Larguía to Brainerd, April 22, 1944, Folder Correspondence of Brainerd with Persons in Argentina, 19481950, WILPF, Part 3: US Section, Series A4, Part 1, Box 23, DG043, SCPC.

76. Edelman, Banderas, 79 (quote), 81-84, and interview with author, Buenos Aires. 2009. $67-69$.

77. Oliver, Mife, 41-42, and interview, 51; "Homenaje a Winston Churchill," Sur, no. 87 (December 1941):

78. La Hora, September 13, 1941, 4 . 
Ana Rosa Schlieper de Martínez Guerrero, an upper-class philanthropist, Radical, and president of both the UAM and the Inter-American Commission of Women, headed the Junta and its national mobilization. Ratto became secretary general and key organizer, and Oliver became vice president. Prominent union militants, artists, educators, professionals, intellectuals, and socialites-AFA and UAM members and PCA activists and sympathizers among them-joined the leadership. ${ }^{79}$ Women of all classes, ethnicities, and pursuits, including blue- and white-collar workers, formed neighborhood chapters in Greater Buenos Aires, yet most members were low- and middle-income housewives. Thanks largely to the Party, recalled a working-class woman from a peripheral industrial neighborhood, the Junta was "popular and pluralist." 80 Far more successful in attracting a broad base than the UAM, the Junta spread through much of Argentina. ${ }^{81}$ Its leaders asked acquaintances in the provinces to organize affiliates and toured these areas to guide their efforts. Few women in the interior worked in factories, but the Junta tried to recruit those who did. More commonly, it mobilized lower- to middle-class homemakers, teachers, employees, and small farmers. ${ }^{82}$ By 1943, the group claimed to have 45,000 members, probably an exaggeration. ${ }^{83}$ Still, it was the largest Argentine women's political organization up to the time of Peronism.

Rarely the top leaders, Communists nevertheless played crucial roles in the interior. One who did was Polly Yánover, a militant of poor Jewish immigrant origins who was credited with organizing the Tucumán chapter by enlisting her wide circle of friends. ${ }^{84}$ Originally from Paraguay, Julia Zarza played a similar function in the village of Oberá, Misiones. Oberá was among the vibrant Junta affiliates in remote northeastern areas, where Communists had mobilized small farmers, peons, and agricultural workers on quebracho (lumber used in tanning) plantations. Zarza met many people by working alongside her husband Marcos Kanner, a Communist Party leader and labor organizer, and receiving militants

79. Valobra, "Formación," 139-140; Deutsch, “Argentine Women."

80. Argentina Libre, September 18, 1941, 12; La Hora, February 27, 1942, 5; June 17, 1942, 5; Franco, Mujeres, 26-30 (quote on 29).

81. For Valobra, in “Formación," 145, this suggested that the Junta's maternalist antifascism trumped UAM's women's rights focus, although, as described below, the Junta also issued non-maternalist women's rights appeals.

82. My conclusions on the Junta's composition are based on archival and library research and consultations with local historians, residents, and descendants of Junta members in Buenos Aires and six provinces. On the interior, see also La Hora, March 19,1942, 5; May 8, 1943, 6; Orientación, October 22, 1942, 3; Edelman, Banderas, 86; and Mujeres en la Ayuda (1942), 14-17.

83. Ana Rosa Schlieper de Martínez Guerrero to President Pedro P. Ramírez, June 30, 1943, Centro de Documentación e Investigación de la Cultura de Izquierdas en la Argentina, Buenos Aires.

84. Polly Yánover de Cutín file, Subfondo Archivo de Redacción de Qué sucedió en 7 días, Fondo CEN, Archivos y Colecciones Particulares, Biblioteca Nacional, Buenos Aires; Lucho Cutín and Samuel Kaufman, interviews with author, Tucumán, 2013. 
in her home. These experiences paved the way for her efforts as secretary of the Junta chapter. ${ }^{85}$

Although the primary mission of these and other Junta chapters was to aid the Allies, that objective was tied to local concerns. Junta members regarded World War II as a continuation of the transnational conflict between democracy and fascism inaugurated in the 1930s. The battle raged on many fronts, including neutral Argentina, where the government was increasingly dictatorial and the far-rightist Nacionalistas were gaining strength. Junta members contributed to the democratic cause overseas by supplying the Allies, and at home by defending the country's independence and freedom. "By helping the brave soldiers of liberty," said Ratto, "we . . . help our own selves." Allied and Argentine struggles for liberty and democracy were intertwined, and the Junta's ideological solidarity encompassed Argentina as well as the combatant nations. ${ }^{86}$

As it opposed fascist subjugation of women, the Junta upheld their rights. Influenced by their UAM roots, Junta leaders considered Argentine democracy defective because it excluded half of the population. While Schlieper championed female suffrage in speaking engagements abroad, she and her colleagues usually alluded to such issues more subtly in Argentina, emphasizing how the Junta trained women to work together and conduct duties vital for governance and national defense. It engaged ordinary women in their residences, workplaces, farms, and neighborhoods, diminishing their isolation and preparing them for involvement in civic affairs. Members followed democratic procedures, gave speeches, elected officers, and compiled reports that they presented at national conventions, where representatives deliberated and voted on policies. ${ }^{87}$ The Junta described the participants in these activities as citizens and patriots, in terms disconnected from motherhood. According to Schlieper, the convention delegates' skills showed that Argentine women soon would share leadership in society with men. ${ }^{88}$ One such delegate, Margarita de Barraza, an impoverished mestiza with six children, epitomized this growing self-confidence and empowerment. Barraza, who learned to knit to serve the

85. Libertad Kanner and Elsa Furtenbach, interview with author, Oberá, 2013; Edelman, interview; María Lida Martínez Chas, Marcos Kanner: militancia, símbolo y leyenda. Crónica de una pasión revolucionaria (Posadas: Editorial Universitaria, 2011)).

86. La Hora, September 13, 1941, 4; September 14, 1941, 5; Ratto in Solidaridad internacional para la defensa de la patria. Conferencia pronunciada el día 12 de diciembre de 1941 en la "Junta de la Victoria" (Buenos Aires: n.p., n.d.), 5, Caja Mujer-Niñez, Archivo del Partido Comunista, Buenos Aires.

87. Martínez Guerrero speech, Box 76, Folder 7, IACW, A, Stevens Papers, SLHU; Junta de la Victoria, Ayuda de las mujeres argentinas a los paises que luchan contra el nazismo. 13 septiembre 1941 -13 enero 1942 (Buenos Aires: n.p., 1942), n.p.; La Voz del Interior (Córdoba), October 1, 1941, 7; October 27, 1941, 7; La Capital, June 7, 1942, 13; Schlieper to Ramírez; La Hora, May 10, 1943, 3, and May 21, 1943, 5.

88. La Hora, April 15, 1942, 5. 
Allies, told the 1943 national meeting that the Junta's "sentiment of solidarity" made her feel genuinely useful for the first time in her life. ${ }^{89}$ Previously bound to chores in her home and farm, she, like other Junta members, now proudly shared in an international crusade for justice that expanded her narrow domestic horizons and fostered her citizenship.

The Junta's national meetings also promoted cohesion and solidarity within the organization, as revealed in a rare document that offers the entire proceedings of its first convention in 1942. There, Junta members from around the country described their accomplishments, dreams, and limitations. What stood out most were the reports of the provincial delegates, who related their struggles with impassable roads, dire poverty, government and Nacionalista hostility, and arduous double-duty days. A chapter in a destitute region barely managed to assemble a few packages of cigarettes, bandages, and provisions for the Allies. Alternately heartbreaking and inspiring, these accounts won the admiration and sympathy of other Junta members and stimulated conviviality, understanding, and enthusiasm among all. ${ }^{90}$

Occasions which brought together members of different strata prompted similar feelings. In April 1943, Junta representatives from the federal capital toured Chaco and Corrientes. Several affiliates in the Chaco countryside, an area teeming with Communist activity, invited them to a rustic evening meal at a farm, where over 500 Junta members and sympathizers greeted them. A Bulgarian band played music, and criollos and immigrant settlers danced in their native garb. The festivities lasted till daybreak. According to a reporter, the Porteñas displayed a friendly, down-to-earth manner free of "differential treatment" toward locals, who discussed rural issues with them and taught them words in their native tongues. Despite their sophistication, the guests were cordial to rich and poor alike, which the journalist attributed to their democratic attitudes. ${ }^{91}$

The Junta extended solidarity to the Allies in numerous ways. Members collected foodstuffs, hospital supplies, used garments, and items for recycling, as well as thread and fabric to utilize in their workshops. In hundreds of these spaces, women made clothing, blankets, bed linens, and bandages, and assembled first aid kits, while others picked up materials to sew or knit at home. The organization devised ingenious means of raising money for these activities.

89. La Hora, May 1, 1943, 6 .

90. Junta de la Victoria, Primera convención nacional de la Junta de la Victoria. 11, 12, 13 y 14 de abril (Buenos Aires: n.p., 1942), 64 and elsewhere. See also La Hora, April 13, 1942, 8; April 15, 1942, 7; and April 18, 1942, 5. On friendships among women activists in the Americas, see Guy, White Slavery; and Marino, "Vergara."

91. El Territorio (Resistencia), April 15, 1943, 2. 
By September 1942, the Junta had distributed 465,036 pesos worth of goods to the Allies. ${ }^{92}$ Junta members worked with their hands, as many of them did in their own homes. For them, as for the Liga and CAMHE, the act of making something invested women in the solidarity project. It helped them imagine and care for the soldiers who received their handmade scarves and sweaters and the babies clothed in the garments they prepared. Maternalism permeated these efforts and Junta rhetoric. President María Inés Zoppi del Valle Pardo of the Resistencia chapter implored "all the mothers and women" of Chaco to join the Junta's campaign for democracy, peace, and tranquility for the home and children. Guided by humanitarianism and "moral duty," our "damas" help the families of needy, suffering countries, she affirmed. We call on the "tenderness that inspires the soul of the woman." She continued, explaining that we, the women of the Resistencia chapter, understand pain and try to alleviate it; we know about mothers because we have mothers in our chapter, where we think of children because we love them. ${ }^{93}$

Junta spokeswomen empathized with European mothers and children. For members such as Dalila Saslavsky, solidarity meant taking on their pain. A friend of María Rosa Oliver, wife of an aristocrat, and close to the Communist Party, Saslavsky was active in the Liga and the Spanish Republican cause. She felt the suffering across the Atlantic and sought to mitigate it but considered her donations and knitting insufficient. Gazing at her own child, Saslavsky imagined the pain of a Czech mother who saw that Nazis had burned a swastika on her son's cheek. She witnessed how a plane flying overhead terrified young Spanish refugees, who feared it would bomb them. Argentines needed to insure an Allied victory so that children would see the sky as heaven rather than hell; then the "V" of the Junta's "victoria" would become an "eternal rainbow." 94 Another Junta member added that mothers could not stop worrying about their children as long as Nazism existed. ${ }^{95}$

Yet, the Junta's aid efforts had a political significance for women that transcended the customary roles of mother and helpmate. Laborers who sewed and knitted for a living tutored women of high society in their crafts. A reporter watched women of diverse origins in Junta headquarters in Buenos Aires squeezed around a table, focusing on their knitting without speaking. This silent communion was a form of solidarity that bridged socioeconomic, ethnic, religious, and political distinctions among members. While they did not necessarily become intimate friends, they worked together

\footnotetext{
92. Statistics in Mujeres en la Ayuda, 43-44. This sum was equal to about US\$ 108,148 at the time.

93. El Territorio, October 20, 1941, 2; December 5, 1941, 3 (quotes); July 6, 1942, 3.

94. Argentina Libre, December 4, 3, 10.

95. La Hora, April 30, 1942, 6.
} 
harmoniously. ${ }^{96}$ Inverting hierarchy, sharing knowledge across class lines, and creating camaraderie laid the groundwork for a true democracy, according to Ratto. ${ }^{97}$ Junta leaders rarely criticized the class structure directly, however, and postponed major efforts to create a more equal society until after the war. In accord with Popular Front and Soviet wartime policy, their priority was an Allied victory, which required unity among all social strata.

A mathematician who had been active in the student, antiwar, and Spanish Republican aid movement, Ratto distinguished the Junta's solidarity from maternalist philanthropies, which simply donated money and goods. The Junta was "an organization of work and struggle" whose members understood that every piece they knitted was a means of defending - as if through combatwhat they cherished. ${ }^{98}$ The members constituted an army of women, fighting for democracy, citizenship, and a just postwar order with the weapons they had available. And the Junta explicitly identified itself as such. At its inauguration it addressed itself to British and Russian women-"To you who fight against Nazism" - stating that the Junta de la Victoria was founded to assemble aid for them and to defeat the common enemy. Women loyal to Argentina's historic belief in freedom, they wrote, are joining the "army of liberty" to which you heroically belong. ${ }^{99}$ This and other statements expressed solidarity with women in other countries. Another example: after the United States entered the war, Schlieper handed Eleanor Roosevelt a greeting signed by founding members. ${ }^{100}$ The many signatures evoked Argentine women's respect for Roosevelt's' opposition to inequality and fascism, as well as the unity of purpose across borders. They also described the Junta's concrete actions in support of democracy, such as its shipments of goods to the Allies. These communications answered Victoria Ocampo's plea for subjective and objective solidarity.

Although the Junta' claimed that it represented a "sentiment of human solidarity" divorced from politics, the neutralist and authoritarian Castillo administration worked to hinder its growth and that of other pro-Allied organizations. ${ }^{101}$ The Axis-leaning military dictatorship that overthrew Castillo went further, banning all such groups. Forced underground, the Junta sent funds to a kindred Communist-inspired group in Uruguay, Acción Femenina

96. Argentina Libre, September 18, 1941, 12; Edelman, interview; Ida Halperin, phone interview, 2000.

97. Orientación, November 6, 1941, 7.

98. Junta, Primera convención, 23. On Ratto, see "Biographies of Women Mathematicians," https://www. agnesscott.edu/lriddle/women/sadosky.htm, accessed February 9, 2017.

99. Crítica, September 14, 1941, 4.

100. La Hora, September 27, 1941, 5; Junta de la Victoria, "Las mujeres argentinas a la señora del presidente," 1941, Eleanor Roosevelt Papers, Franklin D. Roosevelt Presidential Library, Hyde Park, New York.

101. Junta, Primera convención, 15. 
por la Victoria, joining its forces with theirs. ${ }^{102}$ In 1945, as Argentina prepared for elections in the following year, the military government allowed the Junta to reopen, although its harassment continued.

The end of the war posed new challenges for the Junta and the PCA. The need to send aid to Europe seemed less compelling, and Juan Perón's election to the presidency in 1946, with strong labor backing, altered the political climate. To renew its appeal, the Junta embraced social welfare and women's issues. Communist strategies also changed, as the PCA leaders sought to compete with Peronists for worker allegiance, and the Soviet victory rendered the Popular Front unnecessary. These circumstances led the Communists to emphasize class struggle once again, as they had before the mid 1930s and did again between September 1939 and June 1941. The party withdrew its support from the Junta, which it now regarded as oligarchical and tied to British and US imperialism. The Junta faded away, and in its place Communists created the seemingly more plebeian Unión de Mujeres Argentinas (UMA) in 1947. It advocated women's rights, social justice, democracy, peace, and Argentine sovereignty. In an ironic twist, the UMA absorbed existing Junta chapters, demonstrating that the latter had a mass base. ${ }^{103}$

Equally ironic, there was some continuity between the Junta and Peronism, which strongly opposed each other. Both represented values of solidarity, and both recognized the existence of inequality, favored social justice, encouraged mutual respect and emotional cohesion among their followers, and empowered them. The Junta tried to weaken class boundaries among its members, while Peronism subverted such barriers in many ways. Juan and Eva Perón implemented social welfare programs and incorporated women into the political system, as the Junta had hoped, even though the Junta spokeswomen considered the Peronist measures demagogic. Both mobilized a wide spectrum of women, including workers and the poor. Even sewing and knitting were important for the two movements, although Peronism saw these activities as means of enabling homemakers to provide for their families. ${ }^{104}$

102. Diario Popular (Montevideo), April 27, 1944, 2.

103. Valobra, "Partidos," and "La UMA en marcha. El Partido Comunista Argentino y las tradiciones y estrategias de movilización social en el primer gobierno peronista: el caso de la Unión de Mujeres Argentinas (UMA),” Canadian Journal of Latin American and Caribbean Studies, 30:60 (2005): 155-183; Mujeres Argentinas, July 15, 1947, n.p., and August. 1, 1947, n.p.

104. Valobra, Del hogar; Eduardo Elena, Dignifying Argentina: Peronism, Citizenship, and Mass Consumption (Pittsburgh: University of Pittsburgh Press, 2011); Natalia Milanesio, Workers Go Shopping in Argentina: The Rise of Popular Consumer Culture (Albuquerque: University of New Mexico Press, 2013); Noemí Girbal-Blacha, "Mujer argentina: el hogar o la fábrica. De costureras y tejedoras en la Argentina Peronista (1946-1955)," Revista de Ciencias Sociales 6 (September 1997): 217-230. 
Nevertheless, as should be clear, the discontinuities were stark. For the Junta's army of women, the enemy was fascism, which in its view included Peronism. For the Peronists, it was the elite, to which some prominent Junta members belonged. Unlike Peronism, the Junta largely abstained from criticizing the oligarchy. The Junta pressed for political democracy and worked to help suffering people overseas, Peronists dedicated themselves publicly to socioeconomic democracy and aiding the underprivileged in Argentina. The Peronist program proved to be far more popular and enduring than the Junta's.

\section{CONCLUSION}

The Liga Argentina Pro Derechos del Hombre, the Agrupación Femenina Antiguerrera, the Comité Argentino de Mujeres Pro Huérfanos Españoles, the Unión Argentina de Mujeres, and the Junta de la Victoria generally conformed to the definitions of solidarity, although two groups fell short in some respects. The UAM's mission was broadening and safeguarding women's rights, while the Junta's focus was on strengthening democracy at home and abroad by aiding the Allies and engaging women. They censured gender inequality but could have addressed class inequality more fully. The UAM did not absorb lower-class women as members, although it worked with them. Perhaps the Junta could early on have framed a statement of postwar social aims to energize workers inside and outside the group without splitting apart its coalition.

Even so, there was a certain confluence among the five movements. All of them were armies of women, manifesting the characteristics of solidarity and political engagement. The many persons who moved from one to another demonstrated the continuity of Communists' efforts to organize women. So too did the fact that the Unión de Mujeres Argentinas explicitly traced its origins back to the Liga, the AFA, the efforts to send Spanish aid, and the Junta, even though the lack of a popular component may have excluded the UAM from this list. ${ }^{105}$ Another common feature was the Communist Party's persistent advocacy of women's citizenship. The Liga and CAMHE did not make pronouncements on women's issues, but the former helped build networks that could form the basis of a revolutionary society, and the latter supported a revolutionary program overseas. The AFA also favored revolution, and like the UAM and the Junta, it upheld women's political rights. The Junta trained women in democratic procedures, modeling public roles at its national conventions.

105. Raíces en el pueblo y unión para la lucha. El nacimiento y los primeros pasos de la Unión de Mujeres de la Argentina, unpublished ms (Buenos Aires: n.p., n.d.), 3. 
To some extent, the Argentine Communist Party “oriented, controlled, or influenced" these solidarity organizations, although we cannot determine the precise extent with certainty. But we do know that the activities of the organizations benefited the party. The Liga assisted Communist prisoners, the AFA supported Soviet foreign policy, the UAM collaborated with Communist workers, and the CAMHE sent aid to a Soviet ally. ${ }^{106}$ The Junta also helped the besieged Soviet Union. Through these groups, the PCA widened its influence among women and other segments of the population and gained new militants. The Junta's involvement in the popular Allied cause heightened the Communist Party's prestige, pointing to local Communists' and leftists' focus on antifascism and their participation in global transnational currents of the 1930s and 1940s. ${ }^{107}$ Communist women's engagement in the Junta expanded their horizons by acquainting them with people and conditions throughout the country. Furthermore, their participation alongside women with legal political affiliations legitimized the Communists, whose party was basically considered illegal.

These Communist-linked armies of women employed and lived by existing gender notions, even as they expanded women's roles and consciousness. Maternalism helped galvanize women's activism, but it was not the only factor. Appeals were more varied and nuanced than one might assume, with messages directed to women not only as mothers, but also as citizens, laborers, and revolutionaries. In one breath, AFA called on mothers to protect life, and in the next it criticized the confinement of women to the home and attacked capitalism. Maternalism tinged the Junta's aid activities but not its training of members for civic engagement. We cannot know precisely which overtures attracted women to membership and activism. ${ }^{108}$ Here we have seen that at least in some cases, leftist and feminist convictions pushed a number of activists to challenge gendered boundaries. One suspects that such convictions moved many more.

University of Texas at El

SANDRA MCGEE DEUTSCH

Paso, El Paso, Texas

106. Paul Preston, in The Spanish Civil War: Reaction, Revolution, and Revenge, rev. ed. (New York: Norton, 2006), 145-151 and elsewhere, and others have noted the limited, cautious, and hesitant nature of Soviet policy in Spain.

107. Leibner, Camaradas, 81 and others, pointed out how antifascism lifted the prestige of Uruguayan Communists. On transnational ties among antifascists, see Pasolini, Los marxistas; Katherine M. Marino, "La Vanguardia Feminista: Pan-American Feminism and the Origins of Human Rights" (Chapel Hill: University of North Carolina Press, forthcoming); and Sandra McGee Deutsch, "Hands across the Río de la Plata: Argentine and Uruguayan Antifascist Women, 1941-1945," paper delivered at the American Historical Association meeting, Denver, January 2017. More research is needed on ties among antifascist groups in Europe and the Americas.

108. I have focused on maternalism, political consciousness, and identity. Historians should also examine such factors as diasporic loyalties, religious beliefs, the desire for prestige, and the wish to be useful in society. 